\title{
Sweet \& sour: Postcolonial professional kitchens in the postmodernity
}

\author{
Carlos Henrique Gonçalves Freitas ${ }^{1}$ \\ CÍNTIA RODRIGUES ${ }^{1}$ \\ VALDIR MACHAdo VALAdÃo JUNIOR ${ }^{1}$ \\ ${ }^{1}$ Universidade Federal de Uberlândia (UFU) / Faculdade de GeStão e NegócIos, UberLÂNdia - MG, BRAZIL
}

\begin{abstract}
Inequality is a historical issue in Brazil, an inheritance of entangled and interdependent social, economic, political and legal injustices. This article summarizes a research on fine-dining restaurant kitchens in the city of Uberlandia, a major economic and migration hub in central Brazil, seeking to expose instances of inequalities replicated in these organizations. It attempts to offer a critical study of unfolding dialogues between its employees' perspectives of their socio-cultural contexts and those of the organizations and their own contextual particularities, using the notions of medievality, global city and foodscape as categories of analysis, with further considerations on organization studies, postcolonialism and postmodernity. Its research corpus' empirical material was collected through shadowing chefs in two restaurants and was analyzed in the light of those categories and considerations. It was possible to interpret that such workers, organizations, and their contexts reproduce symbols, behaviors and representations that may operate as sources of social distinction for their customers, but, paradoxically, may reinforce the inequalities that motivated the research.
\end{abstract}

Keywords: Shadowing. Fine-dining restaurant. Foodscape. Postmodernity. Global city.

\section{Agridoce: cozinhas profissionais pós-coloniais na pós-modernidade}

\section{Resumo}

A desigualdade é uma questão histórica no Brasil, uma herança de injustiças sociais, econômicas, políticas e jurídicas emaranhadas e interdependentes. Este artigo é um resumo de uma abrangente pesquisa sobre cozinhas de restaurantes finos na cidade de Uberlândia, grande polo econômico e migratório na região central do Brasil, buscando expor instâncias de desigualdades replicadas em suas organizações. O presente trabalho faz um estudo crítico do desdobramento dos diálogos entre as perspectivas dos funcionários desses estabelecimentos, a partir de suas contextos socioculturais, e as perspectivas e particularidades das organizações, usando as noções de medievalidade, cidade global e paisagem alimentar como categorias de análise, com considerações adicionais em estudos de organização, pós-colonialismo e pósmodernidade. O material empírico do corpus de pesquisa foi coletado por meio do acompanhamento de chefs em dois desses restaurantes e, em seguida, analisado à luz dessas categorias e considerações. O trabalho revela que os funcionários, as organizações, e seus contextos reproduzem símbolos, comportamentos e representações que podem ser fontes de distinção social para seus clientes, mas, paradoxalmente, podem também reforçar as desigualdades que motivaram a pesquisa.

Palavras-chave: Sombreamento. Restaurante requintado. Foodscape. Pós-modernidade. Cidade global.

\section{Agridulce: cocinas profesionales poscoloniales en la posmodernidad}

\section{Resumen}

La desigualdad es una cuestión histórica en Brasil, herencia de injusticias sociales, económicas, políticas y jurídicas enmarañadas e interdependientes. Este artículo es el resumen de una investigación exhaustiva sobre cocinas de restaurantes finos de la ciudad de Uberlândia -gran polo económico y migratorio de la región central de Brasil-, que se propone exponer instancias de desigualdad replicadas en sus organizaciones. El presente trabajo estudia críticamente el desdoblamiento de los diálogos entre las perspectivas de los empleados de dichos establecimientos, a partir de sus contextos socioculturales, y las perspectivas y particularidades de las organizaciones, usando las nociones de medievalidad, ciudad global y paisaje alimentario como categorías de análisis, con consideraciones adicionales en estudios de organización, poscolonialismo y posmodernidad. El material empírico del corpus de investigación se recolectó por medio del seguimiento de chefs en dos de esos restaurantes, y luego se analizó a la luz de esas categorías y consideraciones. El trabajo revela que los empleados, las organizaciones y sus contextos reproducen símbolos, comportamientos y representaciones que pueden ser fuentes de distinción social para sus clientes, pero, paradójicamente, también pueden reforzar las desigualdades que motivaron la investigación.

Palabras clave: Ensombrecimiento. Restaurante sofisticado. Foodscape. Posmodernidad. Ciudad global. 


\section{INTRODUCTION}

The contrasting sweet-and-sour flavor is present in several cuisines and may open a discussion to a multitude of influences on a particular type of organization: fine-dining restaurants in Brazil. This article seeks to discuss contrasting elements derived from postcolonial and postmodern categories of analysis. They may often allow contrasting perspectives to their specific and common contexts in cultural, social, economic and political terms. In a country marked by an entanglement of interdependent economic, social, political and legal inequalities (COSTA, 2018), it is reasonable to presume that related precedents, circumstances, implications and arrangements of such natures could be found in those organizations' social and working contexts.

Fine-dining restaurants may be defined by a set of criteria: high prices based on their food and service, cuisine inventiveness and sophisticated ambiance (GAMBATO and GONÇALVES, 2017); foreign influences, especially French and Italian (BUENO, 2016); care with aesthetics (IPIRANGA, LOPES and SOUZA, 2016); à la carte kitchen organization and design (WALKER, 2014); and kitchen staff with low schooling, qualification, experience and salaries (COELHO and SAKOWSKI, 2014). In that sector, it may preferable to hire unqualified people from less-privileged social background and provide them with in-service training (SUAUDEAU, 2004; FONSECA, 2013). So, their kitchen staff are likely to be originally unfamiliar with the services and products they deliver and their consumption context, as well as such workers may not be able to afford eating at the restaurant they work in. As customers expect distinctive and exquisite dishes, tastes and service, kitchen staff may need training in new skills, acclimatization with new rituals and working with new ingredients and products (BOULUD, 2004; FONSECA, 2013; GAMBATO and GONÇALVES, 2017). The contrast between customers' expectations and cooks' traditions may create possibilities of distinction, as well as of construction, maintenance or reinforcement of inequalities that stretch beyond the organization (MAGUIRE, 2016).

The notions of medieval modernity and emerging countries' global cities (ALSAYYAD and ROY, 2006) may help contextualize fine-dining restaurants in Brazil. These authors argue that today's global cities present a diversity of urban and social enclaves with specific expectations, behaviors, values and norms, resulting in a multiplicity of governance systems, or jurisdictions which in turn reflect almost parallel, often contradictory, realities and interests in the same urban space, as in medieval towns. For them, medievality would configure a category of transhistorical analysis useful to understand contemporary plural scenarios, which may otherwise be characterized by an increasing space and time compression and postmodern antinomies as in Harvey (1989) or Jameson (1998); and by the fragmentation, ambiguity, instability, uncertainty and fluidity of contemporary society as in Judt (2010) or Bauman (2012). It emerges, then, a scenario favorable to equally multiple narratives, values, needs, desires and interests, as well as to less cohesive collective agendas and to identity politics. Thus, the fine-dining restaurant kitchen may house tensions or incongruences resulting from these paradoxically compressed, fragmented, global and multiple contexts.

Departing from Sassen (1991) - who coined the "global city" term as a space of convergence of subnational and supranational entities under a process of integration and transnationalization of economic production stages - Alsayyad and Roy (2006) expand this notion towards discussions on jurisdiction and citizenship in the light of adjacent phenomena, such as deterritorialisation, loss of roots, displacement, fragmentation and ghettoization, which may also lead to postcolonial viewpoints. In this respect, the latter authors' central point on global cities distances itself from the former author's perspective. Alsayyad and Roy (2006) focus on the issue of multiple jurisdictions that may be constructed, developed and sustained in global cities' spaces. However, Sassen's (1991) initial notion does not lose its relevance as a category of analysis centered around an economic infrastructure; she and Marxist thinkers such as Harvey (1989) and Jameson (1998) offer important contributions to any social science investigation. Neither should one ignore the presence of significant economic considerations in Alsayyad and Roy (2006). Global cities' multiple jurisdictions imply other significant economic-related phenomena, which altogether may certainly take place in close and mutual relations.

This article proposes to extend the idea of medieval modernity's contrasts to the organizational and social context of some professional kitchens, a work space and a society's extension that may replicate such paradoxical compressions, fragmentations, and multiplicities. To obtain its empirical material we shadowed chefs in two fine-dining restaurants in the city of Uberlandia. This is a medium-sized city (circa of 690.000 inhabitants) and a major regional center located in the heartland of Brazil that has 
experienced accelerated economic-growth, attracting business and migrants in search of opportunities and employment in the past fifty years (BERTOLUCCI, 2018). Accelerated processes of economic and demographic growth are usually accompanied by social, economic and political repercussions that enhance urban and social fragmentation into enclaves of multiple interests, agendas, expectations, behaviors, values and norms as in Alsayyad's and Roy's (2006) swelling global cities.

\section{Foodscape, Culture \& Politics}

Despite the relevance of food and eating to biological survival (ROZIN, 2007); they have essentially become a cultural phenomenon, a set of social and historically constructed rituals (HEGARTY and O'MAHONY, 2001), or intangible cultural notions. Choices, classifications and behaviors related to them vary, then, according to symbols, representations and other imaginary constructions that reflect world views and social codes present in the way people interact with each other and with their social and natural environment (MACIEL, 2004). It can be interpreted as a symbolic system related to the cultural life of a community. One may, then, define the kitchen as the space of food-and-eating ritual par excellence and, perhaps, a microcosm of society (DOS SANTOS, 2011). Therefore, a professional kitchen may be a legitimate source of perspectives on relevant, rich, complex, intertwined and multiple relationships or on the continuous flow between the organization and its external environment, where sets of arrangements, traditions, rituals, techniques, ingredients, dishes, artefacts and tastes particular to places, regions or countries come alive. Maciel (2004) sees cuisine as a food-and-eating system, while Lévi-Strauss (1968) saw it as a language that unconsciously translates the structures and contradictions - as the sweet-and-sour metaphor - of a society, including abstract representations of social, economic and political arrangements, allowing us to approximate the notions of food and eating and of kitchen and cooking to the idea of identity (COLLAÇO, 2009; BUENO; 2016).

Food, eating, kitchen, cooking and cuisine together may encompass ideas, practices, behaviors, preferences and artefacts that operate in a complementary, supplementary or dual fashion; implying multiple perceptions and expressions of a group's way of life (MACIEL, 2004). They may take form of table manners, practices and behaviors linked to the social ritual of eating together (LINARES and TRINDADE, 2011); patterns of consumption and taste (DOS SANTOS, 2011); and other representations that extrapolate their immediate domain and permeate abstract, economic, social, and political relations (DOS SANTOS, 2011), which are organized within a group, in a given territory and time in the notion of a cuisine (MACIEL, 2004). It may emerge, then, the relationship between a group's culinary and identity (FISCHLER, 1988; ROZIN, 2007; DE SOLIER, 2013). It may also emerge the role of cuisine in the process of identification with political institutions, such as a nation-state (BUENO, 2016). Such food-and-eating notions become closer to an imagined national identity (ANDERSON, 1991; HOBSBAWM, 2000), and their social and political dimensions may be identified as markers of social capital and distinction (BOURDIEU, 1984; ROZIN, 2007).

Yet, these notions may be considered under a single one: that of foodscape, or a landscape of food-and-eating dynamic cultural spaces and practices that are materially and socially mediated and constructed within society by its individual, groups and institutions (JOHNSTON and BAUMANN, 2010; JOHNSTON and GOODMAN, 2015). Such landscape is also an arena in which public, private, individual, institutional, social, political and economic forces interact, representing what foods are valued, produced, sold and consumed; how and what agents can influence or control resources, and individual or collective choices; and who and how one takes part in this system, whether as consumer, producer, opinion maker or any other agent. Foodscape reflects dialectical relations between socially constructed, interrelated cultural elements, artefacts and other reifications, including their political and economic dimensions (JOHNSTON and GOODMAN, 2015). However, it may also be the arena of non-deterministic processes, in a way comparable to a cosmology of influences that results not necessarily in a negative perspective of cultural loss, but in the transformation of the initial object or in the intensification of some of its defining traits (SAHLINS, 1988).

Complementary, the way group members prepare their food may indicate their level of civilization (LÉVI-STRAUSS, 1968), and what and how people eat may even help define them and understand their social environment (ROZIN, 2007). Foodscape may be a key to individual and group identities and central to power arrangements in terms of identity, identification, distinction and politics, as in the light of postcolonial studies and the so-called process of globalization (BOURDIEU, 1984; BUENO, 2016; 
WARDE, 2016). A group's cuisine, hence a foodscape, reflects a set of culinary habits, practices and preferences that can reveal socioeconomic aspects such as patterns of consumption, production, labor division and relations, land and wealth distribution, and political arrangements.

However, Warde (2016) indicates that although eating can contribute to the definition of an identity and of a way of life; consumption, under any foodscape, can be characterized by the lack of any noticeable trait and generalization. If, like any other cultural expression, foodscape can represent an element of creation, innovation and continuity of social relations that strengthen collective and individual identity, they can also give a sense of alterity and exclusion in terms of class, ethnicity, gender or nationality (MINTZ and DU BOIS, 2002). A national kitchen can materialize group identity within a given time and territory, reinforcing the sense of belonging (MINTZ and DU BOIS, 2002; COLLAÇO, 2013), but it can also be a marker of cultural domination or postcolonial relations (ZAMAN, SELIM and JOARDER, 2013). It can also lead to food consumption without historical or cultural links and disconnected from local socio-cultural practices, decontextualized without contributing as an element of collective identification (FISCHLER, 1988). Given a dynamic and heterogeneous foodscape, its cultural and material arrangements may be marked by unequal economic and political dimensions (JOHNSTON and GOODMAN, 2015), and kitchen workers, as we will see, might be considered in the light of postmodern and postcolonial subjectivities, due to their fragmented, multiple, displaced and decentralized condition as migrants (HALL, 1992).

\section{Nation Building, Media \& Gentrification}

Geertz (2000) emphasized that third-world nation building might have been subject to updated versions or reinterpretations of the colonizer's past, although recognizing that its elites may have had their own local or transversal sources of inspiration, generating new visions of country and nation. By accepting that a society's cuisine can translate structures in which the group functions (LÉVI-STRAUSS, 1968), one may also accept that there are links between the group's foodscape and other social categories of analysis, such as migration, demographics, power and class, which are not alien to colonial nation building.

Food and eating are a cultural phenomenon that corresponds to a historical path (HEGARTY and O'MAHONY, 2001). It is constituted within, contributes to and occurs in a specific foodscape of interacting public, private, social, political and economic forces (JOHNSTON and GOODMAN, 2015). According to Wilson and Donnan (1998), nation and state do not always fit into anthropological notions about culture, because often the three do not always share the ideas of integrity, unity, temporal and spatial linearity and separation. It would be perfectly acceptable to have multiple cultures in one particular social space and time (GEERTZ, 1973). Yet, Geertz (2000) admits studying culture and nation to understand postcolonial states.

Nation building and national cuisine are part of a specific foodscape, with traditions and histories that unfold in some form of identity (COLLAÇO, 2009; HOBSBAWM, 2000; BUENO, 2016). They may contribute to interpretations about how different groups can come together in a given society, or how multiple sets of fragmented food-and-eating traditions can simultaneously produce parallel or converging foodscapes often misinterpreted as homogenous. In fact, Brazil's foodscape is rich and diverse as its people, resulting from a coloniality common to many South-American societies (QUIJANO, 2000). In Brazil, a variety of ethnological shades and a diversity of cultural traditions characterize a "new people", formed through migration from all continents, under equally diverse circumstances, favoring diversity, but also making it a highly porous and dynamic cauldron resting on inequal economic and power arrangements and structures (RIBEIRO, 2006).

Towards the end of the $19^{\text {th }}$ century, in Brazil, European immigration intensified in an attempt to replace the slave workforce and to "whiten" the population (ALVIM, 1999). Large numbers of Portuguese, Spanish, Germans, Italians and Levantines, mostly Christians, arrived (FAUSTO, 1999), followed by Japanese immigrants, too (SAKURAl, 1999), contributing to complex, diverse and uneven power arrangements and structures in society in terms of class, labor division, political participation, rentism and concentration of means-of-production control and power, with their due implications in society's cultures' different spheres, including its foodscape. Important foods items were inherited from native Brazilians (MACIEL, 2004), the Andes 
(FERNÁNDEZ-ARMESTO, 2004) or Africa (CÂMARA CASCUDO, 2004). Portuguese trading routes contributed to the Columbian Exchange of fruits and vegetables among continents (MACIEL, 2004), but such migration of tastes, ingredients, techniques and traditions was also adjusted according to local environmental, cultural, social, economic and political contexts (CÂMARA CASCUDO, 2004). Later on, popular Italian restaurants, in Sao Paulo, became a significant imagined cultural expression by adjusting Italian food-and-eating practices and products to the local taste (COLLAÇO, 2009). From a postcolonial perspective, those encounters may be interpreted as negotiation among multiple identities in different dimensions, and as reconstruction of cultural representations and subjectivities (HALL, 1996).

Collaço (2009) also shows how, from 1950 to 1970, Italian restaurants in São Paulo represented a source of leisure for the city's emerging cosmopolitan bourgeoisie - Rodríguez-Ferrándiz (2014, p. 329) argues that "cultural consumption is distinguished by a voracity for the new and by a demand for distinction which is more pronounced than in other sectors of consumption". Such use of culture has been discussed in Adorno (2005) and Bourdieu (1984) in their respectively conceptualizations of pseudo-individualization and of habitus, social capital and distinction. Further on, this would connect with the food-andeating business growth, and with restaurants gaining importance in social and economic dynamics (HENDERSON, 2011). Add to this that, in Brazil, the notion of "middle class" is close related to the access to forms of consumption, entertainment and leisure similar to those Brazilians associate with Europe and North America (SALATA, 2015), reinforcing the notions of cultural capital and class (BOURDIEU, 1984), and of distinction through food and eating (BUENO, 2016), particularly in light of the rise of notions such as celebrity chef and media gastronomy.

Such a foodscape may hint at the convergence of quite different groups, from multiple and diverse perspectives, expectations and discourses. Such a complex and heterogenous resulting foodscape may allow interpretations about food and eating that encompass intrinsic power relations and socioeconomic elements in Brazil's coloniality. This landscape has been tainted by inequality, since Brazil's colonial past, and perpetuated through economic, social, political e juridical entanglements (COSTA, 2018), as well as reinforced as the food-and-eating business expands in combination with social media and the globalization of markets and tastes in a process of gentrification through food (FREITAS and MEDEIROS, 2018).

With the globalization, the arrival of French chefs to work at hotels and restaurants, the country's currency stabilization and the opening to foreign products also are important considerations (ROCHA, 2016). A new generation of young Brazilian chefs also arose, particularly those coming from the middle classes and trained in France or the US; High-income Brazilians' taste also became increasingly influenced by the expansion of food-and-eating business, media and foreign TV shows broadcasted locally; or by Brazilians' gastronomic experiences when traveling abroad (BUENO, 2016). As a result, Brazilian society's inequalities tend to be reflected in the fine-dining restaurants' scene, when customers demand food-and-eating ambiance, products and services alien to most of the workers who deliver them (FREITAS and MEDEIROS, 2018).

The celebrity chef and food-and-eating TV shows have become almost a binomial like bread and butter, often essential to businesses' success, influencing tastes, consumer behavior, brand equity and other distinction markers (HENDERSON, 2011; LENGYEL and GATLEY, 2016). The phenomenon of food-and-eating media stars and online influencers may add further relevance to the idea of modern life as a collection of spectacles, in which every experience lived by people can turn into some kind of staged act, as a desubjectivation or resubjectivation of oneself or as an unwanted agency in the face of market forces and state techniques (DEBORD, 2006). Complementary, Foucault's notion of biopolitics implies subjectivation as the agent becomes part of a set of control technologies (FOUCAULT, 2008), which is not imposed but embraced by that same agent, who internalizes them under the rationality of governmentality and the notions of human capital and of a dispute between the subjects of interest and of right (FOUCAULT, 2008).

Further, when BBC's MasterChef program was franchised and displayed in Brazil, it was translated into another public and cultural environment, into another foodscape, and multiple displacements occurred (FREITAS and MEDEIROS, 2018). From a postcolonial perspective, in contemporary times - marked by postmodernity - this cultural encounter can be best interpreted as a negotiation between and through displaced multiple identities and national borders in different dimensions, and as a reconstruction of cultural representations and subjectivities (HALL, 1992, 1996). Recalling Bauman (2012), one may say that issues of subjectivity, existence, and power remain in a fluid world full of multiple, divergent, and concurrent acts of fragmented spectacles operating as a Debordian vortex. 
Thus, the two contrasting yet converging perspectives to this analysis. First, a postcolonial one, re-enacting the colonial attempt of domination or imposition of discourses, e.g. by transplanting foreign food-and-eating shows to Brazil. Second, by recognizing contemporary visions labelled as liquid modernity, hypermodernity or postmodernity, and characterized by notions such as multiplicity, narratives, media, hyper-consumption, fragmentation, relativism, instability and uncertainty in several dimensions, but essentially exposed through particular types of discourses and sets of practices (FOUCAULT, 2008).

The postcolonial perspective is closely related to the notion of media gastronomy, summarizing gastronomy's rising media presence due to the celebrity chef figure, the role of the foodie movement - a phenomenon resulting from people's voracious consumption of exotic flavors and cooking-related products and media (JOHNSTON and BAUMANN, 2010; HENDERSON, 2011; JOHNSTON and GOODMAN, 2015; LENGYEL and GATLEY, 2016) - and their influence in media itself, consumption and social behavior. Media gastronomy and food are the two sides of the same token, contributing to a process of gentrification through food and eating (ZUKIN, LINDEMAN and HURSON, 2015).

Still, society's multiplicity interacts with traditions in a transformation process. While traditions imply resistance to change (HOBSBAWM, 2000), they can be genuinely constructed within, by and for society, or invented by the holders of power on behalf of their vested interests (ANDERSON 1991; HOBSBAWM 2000), e.g. of nationalism or colonialism. On the other hand, one may assume that transformations may be greater when traditions are less rooted in society, or find less popular adherence by or legitimacy among its members. In postcolonial terms, subjectivities coexist on a dynamic border or in an interdependence state characterized not by clear-cut subjects, but rather by "mobility, uncertainty and multiplicity of the fact of the constant bordercrossing itself "(GROSSBERG, 1996, p. 92). Novelties and changes may be closer to Hall (1996) than to claims of local identities or to a binary view on the relationship between the colonizer and the post-colonized as in Said (2003) and Spivak (1994). And this might be the case of Brazil's fine-dining restaurants' foodscape.

However, while foodies may have positive or negative connotations (JOHNSTON and BAUMANN, 2010), naming someone a foodie implies distinction between one who possesses knowledge and taste about food and those who do not, close to the issues of class and distinction as in Bourdieu (1984). Further, in Brazil, cultural orientation to the new (HOFSTEDE, 1994) may be accompanied by nostalgia for some coloniality roots, and fine-dining restaurants might explore it as their customers seek consumption as distinction through novelty, colonial legacy identification or insertion in Western discourses, enhancing historical inequalities. But consumption need not to be a negative; food consumption may help knowledge dissemination as foodies and media gastronomy attract more people to richer foodscapes and alternative values and practices (JOHNSTON and BAUMANN, 2010), or it may carry a perceived moral proposition to consume better and with more responsibility (DE SOLIER, 2013).

As food-and-eating symbols, representations and discourses present in consumption rituals may be affected by foodie practices and media gastronomy, in Brazil, these trend-building sources exert locally a significant influence similar to those by former colonial powers (FREITAS and MEDEIROS, 2018). One should recognize that foodscapes may reflect social phenomena that bring the notions of cultural capital and economic capital into the same arena, despite the particular theoretical framework of each one. While cultural capital indicates multiple and broad relations, economic capital has the weight of a historically infrastructural and deterministic framework. The former closer to postmodernity considerations, from Pierre Bourdieu to Michel Foucault and Zygmunt Bauman. The latter more sensitive to an ethical stance intrinsic to postcolonial studies, from its foundations in Karl Marx to Edward Said, Kwame Anthony Appiah and Stuart Hall.

Thus, the notion of human capital, and of subjects of interest and of right (FOUCAULT, 2008) may be complementary to the notions of habitus, social capital and distinction (BOURDIEU, 1984), reinforcing the importance of considering individual action alongside collective agendas and efforts, with particular relevance in a world haunted by modernity's failure and the aporia between public and private concerns (BAUMAN, 2012). Yet, media gastronomy and gentrification may lead to the reformulation of symbols, practices and representations in foodscapes, to the decentralization of identities, and to people's displacement, reaching customers, society in general, and particularly kitchen workers in fine-dining restaurants. One may benefit from an unorthodox study approach to the meeting of habits, tastes and other symbols valued by trendsetters - who already enjoy greater cultural capital and are capable of influencing what it is a 
source of distinction or not - with the set of habits, tastes and other symbols valued by the workers who cater for the former. Within a fuzzy context, the process of gentrification through food and eating may reinforce the very inequalities that motivated the present research.

\section{METHODOLOGICAL PROCEDURES}

We attempted to offer a critical analysis and interpretations about unfolding exchanges among fine-dining restaurants, its kitchen staff and their different cultural and historical perspectives and contexts, particularly in terms of postmodern and postcolonial considerations. For empirical material collection, we used shadowing (CZARNIAWSKA, 2007; MCDONALD and SIMPSON, 2014), accompanying chefs, cooks and porters in two fine-dining restaurants ("Montecarlo" and "Atelie Sofia") in Uberlândia for two months. This choice was based on a fine-dining restaurant short-list (TRIPADVISOR, 2018), on view exchanges with local foodies and on visits to eight of the short-listed restaurants.

Initially, we focused on their executive chefs' work, and how they communicated, organized, motivated, guided, instructed, corrected, helped, hindered, questioned, responded, delegated, ignored and interacted with their kitchen brigade, attendants and management staff in their daily routine (QUINLAN, 2008). The material included observations and ad hoc testimonies from those chefs, followed by note-taking. It was not limited to a descriptive process and encompassed interactions among the shadower, the shadowees and other people present in the shadowing space (VÁSQUEZ, BRUMMANS and GROLEAU, 2012; JOHNSON, 2014). As relevant rapport and trust were established (GOBO, 2008; QUINLAN, 2008), we also included observations, testimonies and interactions with brigade members, including behaviors, actions and speeches about their wider social context within and outside of the organization (VÁSQUEZ, BRUMMANS and GROLEAU, 2012). In addition, photos were taken as part of the empirical material.

Particular attention was given to ethical considerations and the researcher's preparation (JOHNSON, 2014), as the shadowing involves the negotiation of spaces, feelings, ideas, thoughts, privacy and identities, exposed to relationships of undefinition, belonging, presence and visibility (QUINLAN, 2008). Another aspect carefully considered was the balance between familiarity and strangeness (GOBO, 2008; VÁSQUEZ, BRUMMANS and GROLEAU, 2012) due to the shadower's previous ten-year experience as a cook, chef and restaurant consultant, and its potential influence on observations and analyses.

The fieldwork totaled 216 contact hours in two months, generating 309 photos and 49 pages of field notes. These were taken bearing in mind five cognitive modes of empirical material collection: listening, questioning, observing, reading and reflecting (GOBO, 2008). The filled notebook pages were divided into three columns ("what I see"; "how I feel it"; and "scaling it up") based on Gobo's (2008) annotation categories (observation, methodological, theoretical and emotional notes). The first column corresponded to descriptions of tasks, symbols, interactions, locations, procedures, etc., recording information as heard or observed (e.g. linguistic register, jargon, slang, etc.). The second was reserved for considerations on sensations, emotions and reactions. The third was dedicated to possible links among the observations, our theoretical and methodological foundation, the restaurant's context and its staff's professional and social contexts. Due to à la carte kitchens' lack of free space, time pressure, simultaneous tasks and intense routines, formal interviews were avoided not to compromise the workflow. Annotations about menus, datasheets and signs were also surveyed. The ad hoc testimonies were conducted as discursive interviews, often with a speculative bias, in which the shadowees had the freedom to conduct them according to their own terms, objectives, schemes and language (GOBO, 2008). 


\section{ANALYSIS OF RESULTS}

In Uberlandia, TripAdvisor (2018) listed an array of 79 pizzerias, 31 Brazilian and 6 American steakhouses, 12 sushi and 10 sea-food places, and numbers of national-cuisine restaurants (72 Brazilian, 11 Mexican, 20 Italian, 5 Chinese, 3 Lebanese, 2 French, 1 German, 1 Australian, 1 Indian and 1 Spanish), suggesting the incorporation of a variety of cuisines and tastes into its population's entertainment habits. The city has also been receiving increasing numbers of immigrants from several regions from Brazil and the world over five decades, due to its fast and steady development, becoming an important socio-economic center (BERTOLUCCI, 2018). These newcomers' backgrounds, personal and professional histories have contributed to the city's diversity in terms of cultures, aspirations and discourses. Such diversity and accelerated expansion also near the notion of global cities of emerging countries in Alsayyad and Roy (2006), leading to dynamic interactions among elements of regionality, internationalization and social inequality. If one considers some aspects present in Bauman's fluidity (2012), it is possible to admit some resulting pressure on society's traditions and some tendency to form groups that are subject to multiple and fragmented interests and expectations.

\section{Heat and Emotions}

Initially we focused on the Montecarlo, located in an upper-middle class neighborhood and offering local adaptations of French and Italian classics to their local customers' food preferences, taste and profile, yet keeping alive their regional references and offering good-value for money and the chance of distinction through food-and-eating. Its dining room is comfortable; its attendants wear classic uniforms; and its crockery, glasses and cutlery are of high quality, all compatible with important attributes in an à la carte restaurant (AZEVEDO, MOURA and SOUKI, 2015). It caters for 280 seats and it has a delivery service, serving up to 1.600 dishes on a "good Sunday" - according to its head chef. The kitchen becomes so hectic, then, that we were not allowed in there on Sundays. Every week, its kitchen brigade cooks 2,000 kilograms of meat, fish and seafood; 900 liters of bechamel sauce; 600 liters of tomato sauce; and 420 kilograms of raw rice.

Of its eighteen-people brigade, only five were born in Uberlandia, nine came from Brazil's less affluent Northern states, only one had higher education, and none had any formal qualification as a cook, only in-service training. Yet, the challenge they face - to develop not only techniques, but to acquire new knowledge, skills and, perhaps, tastes and behaviors - takes place in a very demanding work environment. The lunch shift can go from 06:00 am to 06:00 pm, with an hour break at 10:00 am. A professional kitchen is a source of physical and emotional exhaustion: long hours standing; constant shouting; yelling; disagreements; large equipment's engine's permanent rattle and noise; intense heat from burners, stoves, grills and bainmaries; simultaneous tasks; and kneeling, stretching and tossing in an endless series of synchronized movements - almost like a jazz band to remind Hatch (1999).

The shadowing also imposes an emotional load, but we did not notice any major quarrels, understanding that observees could have been reluctant to expose themselves to an outsider (EMERSON, FRETZ and SAW, 2011). We did not abandon that state of suspicion helpful to ethnography (GOBO, 2008) and relied on familiarity (EMMEL and CLARK, 2011) to be able to read between lines. We decided not to accept the workplace as a hassle-free space nor ignore its psychic pressure, especially due to kitchen's rigid hierarchy and tradition of bullying (GIOUSMPASOGLOU, MARINAKOU and COOPER, 2018). Despite those possible restraints, there were mutual jokes, complaints and eventual dissatisfaction about each other's performance. This was also aggravated by their long hours, which, somehow, lead them to spend more time among themselves than with their families and make it almost automatic to them to socialize also among themselves outside work in their little spare time, e.g. playing football or drinking their beer. All of that contributed to evidence a hectic working environment full of unfamiliar references to a crew made mostly of migrants (hence with specific cultural traits quite different from the business' ambiance, products, services and customers, as well as with personal histories of sacrifice in search of a better life); and with working routines characterized by a heavy load of demands, high temperatures and the need for a great deal of attention to details. Therefore, they worked under constant pressure and often at their emotional edge.

Notwithstanding, the most significant encounter we had was with Maria (pseudonym). She had been working in the Montecarlo for five years as the kitchen porter responsible for washing all pots, crockery and cutlery, yet finding time to help her colleagues. She refused to accept promotion, despite the owners' insistence. She is 5'2" tall, about 40 years old, 
but looking much older, has three daughters and is divorced. We spoke first in our first week of shadowing. We shared a table during the brigades' lunch and she started a conversation on religion, disclosing that she had been a crack addict for seven years before joining a Neo-charismatic church, joining the restaurant and changing her life. Her duties were very well defined and left her a considerable degree of independence and isolation, providing ideal conditions for a person seeking peace and security, despite every physical and intellectual effort involved in her functions. As she explained, there, she "could be with God without being bothered". In her case, the organization was not a prison, but a remedy for her soul.

All these made it clear that to manage such a group one needs more than technical training, one needs to be able to comprehend and respect multiple e complex contexts, not rarely troubled ones. They may pose potential challenges to management, as limitations to business planning, implementation and operation may arise from different sources of emotional load, related or not to the workplace, affecting performance in terms of products, services and even communication to customers.

\section{Cordiality, Labor and Capital}

Family relations or friendship between employer and employee were a noticeable attribute for hiring staff, both at the Montecarlo and at the Atelie Sofia, both family-owned businesses. Yet, our focus turned to the Atelie Sofia, as the family members were always present during mise-en-place and service, making it better to observe how authority and responsibilities were assigned according to such ties. Its head chef was a forty-year old man who had worked as a cook in Milan (Italy) and Manchester (UK) for 10 years. However, on several occasions, he was corrected about kitchen-related tasks and routines - typically under any head chef's job description - by some of his own staff who had a personal link with the owners. This was made on their behalf, without any further explanation or justification, clearly undermining the chef's management capability. Nonetheless, similar use of family and friendship bonds were also observed in the Montecarlo in several moments.

Such management bypasses expose personal ties' weight in Brazilian society, in business, social and political contexts alike. While Bresler (1997) offers a classic analysis of the parallel between an organization and its family-like culture, in Brazil; Sousa Filho (2008) highlights the influence of patrimonialism in Brazilian discourses. Both authors, to some extent, point to Buarque de Holanda's (1995) notion of cordiality, an attempt to deal with personal ties' weight in Brazilian society. On the other hand, Souza (2019) offers a critique to Buarque de Holanda' work by challenging its potential contribution to a State ideology. However, this paper sees the notion of cordiality as a way Brazilians have found to replace rationality - celebrated from European enlightenment to modernity, but bred un-synchronically in Brazil's path from colony to the republic - as basis of its social, business and political life. The notion of cordiality would be closer to the idea of a favor, in a context marked by patrimonialism, in which public elements have been historically confused with private ones by power holders (FAORO, 2001); not limited to State ideology, but rather reaching individuals' worldviews. Favor established itself as a currency of exchange and mediation in relations both in the public and private spheres in Brazil (MONTEIRO, 1996).

Mumby and Stohl (1991) argue that discourse is how power relations are maintained and reproduced in organizations. From a different perspective, Foucault (2008) places discourse as a fundamental element in the way new control technologies replace the former disciplinary power. Discourse, then, may be internalized as a form of adhesion to a given order. In that sense, it matters less what words denote, as an individual's expression, than how speech acts shape the group's persuasive discourses (VAN DIJK, 2012). We may, then, accept that organizational discourse is also a form of control. In the case of the Atelie Sofia, we may interpret that personal relations and cordiality are not only part of this control, but are perceived by its staff as a token in payment for their work and dedication to the organization, with whose owners, after all, many of them have personal ties. The point we try to make is that such links might, then, be nurtured to the advantage of the organization, but in detriment of professional relations and proper pay of labor. Cordiality may, then, as proposed above, be not limited to an ideological apparatus of control by State and its elite, as seen by Souza (2019), but rather be incorporated to individual worldviews - which, nonetheless, may contribute to that apparatus.

Anyhow, an indirect result from a entanglement among coloniality, cordiality, labor and reward, in a Brazilian organization such as the Atelie Sofia, might be its owners' readiness to pay US\$19,000.00 for a state of the art combined oven (a piece of equipment that combines cooking, grilling and baking methods in an oven), while refusing to pay a month salary above 
US\$540.00 for a Brazilian head chef - as we were told during the shadowing. Such an equipment is too sophisticated and specific for large operations, as in cruise liners and large hotel resorts, exceeding the Atelie Sofia's needs. This acquisition may reflect, then, the owners' view that it is better to invest unnecessarily in an oversized equipment, than to "invest" in the quality of its workforce, in its human capital. All that also expose the way labor has been historically undervalued in Brazil. Schwarcz and Starling (2015) point out how any manual labor used to be done by slaves in Brazil, even in a small local craftsman's shop, such as of a shoemaker, who would become a mere owner and profiteer of his slaves' labor. This led to a detrimental association between labor and subaltern social conditions (CALDEIRA, 1995).

Souza (2019) correctly argues that such a form of networking may also be found in other societies, but one may see cordiality as a local specific phenomenon the same way as the use of "guanxi" in China (CHENTING and LITTLEFIELD, 2001). Notwithstanding, the origins of cordiality may cross the path of coloniality issues. Such a discussion may, then, contribute to evidence the weight of coloniality that still pervades Brazilian society and how a restaurant may reflect aspects of postcolonialism despite the "modernity" of its products and services.

\section{CONCLUSION}

Our first effort was to develop a theoretical foundation around the metaphor of contrasting categories of analyses. This allegory sought to represent how an organizational space, the cuisine of fine-dining restaurants in Uberlandia, could help identify symbols, representations, relationships and narratives that brought in with them different aspects of its wider social context. It recognizes that the organizational space and its inner and outer social contexts are parts of the same whole, and it is difficult to separate them. However, the use of delimited social spaces allowed us to address methodically a multitude of factors and aspects at play. Given the cultural nature of the social phenomena defined by the food-and-eating binomial (ROZIN, 2007) and their resulting multidisciplinary nature (FISCHLER, 1988), it was not possible, neither desired, to do so separately, but rather to address objectives and questions, transversally and often simultaneously.

Aspects of postmodernity and postcolonialism are concomitantly present in the workers' unfolding dialogues with their contexts; in the restaurants' sociocultural and organizational contexts; in Brazil' nation building and in global cities' emergence process; as well as in the workers' responses to and interpretations of the social, economic and political gaps present in their contexts. Such an interplay and overlap of categories of analysis constitute the very essence of postmodernity. They are a central topic, indirectly at least, in Alsayyad and Roy (2006), Judt (2010) and Bauman (2012), and in other theorists whose contemporaneity led them to consider them without overlooking potential incompatibilities among notions of postmodernity and genealogy (FOUCAULT, 2008) and dialectics (HARVEY, 1989; JAMESON, 1998), neither neglecting essential traditional and legitimate view of postcolonialism.

We sought to offer critical and interpretative considerations about dialogues among the organizations and their kitchen staff, including responses and attitudes to specific and common organizational and social contexts. Therefore, we tried to look at those exchanges and positions from different cultural and historical perspectives, particularly adhering to postcolonial and postmodern contrasting categories of analysis. We could see how the owners of the Montecarlo and the Atelie Sofia looked for foreign and/or sophisticated elements such as dishes' presentation sequences; new, exotic or valued ingredients; and aesthetics in plates' decoration and uniforms. We interpreted them as sources of social capital and distinction (BOURDIEU, 1984). However, while such distinction elements can make sense to the owners, and to their organizations and customers; for their workers, those elements may be forms of deepening the inequalities they are subject to, partly originated and explained by postcolonial studies as well as by postmodern multiplicity.

We have also discussed how postcolonial interpretations of the relationship among the Brazilian notion of cordiality, labor and capital may represent an obstacle for those people who can only rely on their labor to provide for themselves and their families; and how those workers have very little access to the yields of their hard work, which is done under extreme physical and psychological strain. Conversely, aspects related to the postmodernity and global cities - such as diversity and multiplicity (ALSAYYAD and ROY 2006), fragmentation (BAUMAN, 2012) and pressure from economic discourses (FOUCAULT, 2008) - instead of discrediting postcolonial approaches to our analysis may support many a relation among those organizations, their kitchen 
workers and their context. The issue does not reside in the diagnostics, but rather in the apparent lack of proper treatment or remedy in face of the weakening of collective discourses and agendas (BAUMAN, 2012). Most kitchen workers we accompanied are in a social fragile position: underpaid, ill-educated, poorly-trained, too busy at work to purse better opportunities, and stalled from any civil action because of an unstable, uncertain, fragmented and confusing social context, which may hinder collective agendas and may favor identity politics (BAUMAN, 2012). After their long shifts and straining working conditions, it may be difficult to think about other things than forgetting or resting, or to find time for night classes or political action.

Finally, in terms of research limitation, first, there was the issue of the shadower's familiarity with Brazilian fine-dining restaurants' kitchens' environment due to his professional history, which we sought to moderate through some ethnographic theoretical foundation and training before the shadowing, particularly regarding field behavior and ethical matters. Second, there was a lack of a single discipline theoretical foundation specific to the research's topic and objects, given their multi, inter or transdisciplinary nature. We tried to deal with its wide disciplinary nature by resorting to authors, research and publications from multiple fields of knowledge.

As for future research suggestions, we found a gap in qualitative and quantitative studies tracking the whereabouts of former cooks in Brazil. Staff turnover seems quite significant, nonetheless, we could not find any study that investigated whether those workers, most of them very young, continue in the profession, for how long and in what capacity they do so; or whether they change their professional path altogether and in what direction. Still during the shadowing, we observed the staff's frenetic use of smartphones in their break, it could be worth an investigation that would identify what kind of social media those workers use and an analysis of their discourses- e.g. they seem to favor particular dating and video-based applications, and voice messages and image-based content over written ones.

\section{ACKNOWLEDGMENT}

This study has been partly financed by the Coordenação de Aperfeiçoamento de Pessoal de Nível Superior, CAPES (Brazil's higher education personnel research council), Finance Code 001." 


\section{REFERENCES}

ADORNO, T. W. On popular music. In: FRITH, S. and GOODWIN, A. (Eds.). On record. London: Taylor \& Francis, 2005.

ALSAYYAD, N.; ROY, A. Medieval modernity: On citizenship and urbanism in a global era. Space and Polity, v. 10, n. 1, p. 1-20, 2006.

ALVIM, Z. M. F. O Brasil italiano (1880-1920). In: FAUSTO, B. (Ed.). Fazer a América: A imigração em massa para a América Latina. São Paulo: EUDUSP, 1999.

ANDERSON, B. Imagined Communities: Reflection on the origin and spread of capitalism. London: Verso, 1991.

AZEVEDO, L. G. M. R. P. P., MOURA, L. R. C.; SOUKI, G. Q. Um estudo qualitativo dos atributos para a escolha de um restaurante. Revista Acadêmica São Marcos, v. 5, n. 1, p. 25-51, 2015.

BAUMAN, Z. Liquid Modernity. Cambridge: Polity Press, 2012.

BERTOLUCCI, L. Similaridades e diferenças demográficas em municípios polos. In: Dinâmica Socioeconômica de Municípios Selecionados, v. 1. Uberlândia: CEPES/IERI-UFU, 2018.

BOULUD, D. Conselhos a um Jovem chef. São Paulo: Anhembi Morumbi, 2004.

BOURDIEU, P. Distinction: A social critique of the judgement of taste. Cambridge, MA: Harvard University Press, 1984.

BRESLER, R. Roupa surrada e o pai: Etnografia em uma marcenaria. In: PRESTES MOTTA, F. C.; CALDAS, M. Cultura Organizacional e Cultura Brasileira. São Paulo: Atlas, 1997.

BUARQUE DE HOLANDA, S. Raízes do Brasil. São Paulo: Companhia das Letras, 1995.

BUENO, M. L. Da gastronomia francesa à gastronomia global: Hibridismos e identidades inventadas. Caderno CrH, v. 29, n. 78, p. 443-462, 2016.

CALDEIRA, J. Mauá: Empresário do Império. São Paulo: Companhia das Letras, 1995.

CÂMARA CASCUDO, L. História da Alimentação no Brasil. São Paulo: Global, 2004.

CHENTING S.; LITTLEFIELD, J. E. Entering Guanxi: A business ethical dilemma in mainland China? Journal of Business Ethics. v. 33, n. 3 , p. 199-210, 2001.

COELHO, M. H. P.; SAKOWSKI, P. A. M. Perfil da mão de obra do turismo no Brasil nas atividades características do turismo e em ocupações. Brasília, DF: IPEA, 2014.

COLLAÇO, J. H. L. Sabores e Memórias: Cozinha italiana e construção identitária em São Paulo. 2009. Doctoral Dissertation (Doctor Degree in Social anthropology) - Faculdade de Filosofia, Letras e Ciências Humanas, Universidade de São Paulo, São Paulo, 2009.

COLLAÇO, J. L. H. Gastronomia: a trajetória de uma construção recente. Habitus, v. 11, n. 2, p. 203-222, 2013.

COSTA S. Entangled inequalities, state, and social policies in contemporary Brazil. In: YSTANES M.; STR ØNEN I. (Eds.). The Social Life of Economic Inequalities in Contemporary Latin America. Basingstoke: Palgrave Macmillan, 2018.
CZARNIAWSKA, B. Shadowing: And other techniques for doing fieldwork in modern societies. Malmö: Liber AB, 2007.

DE SOLIER, I. Making the self in a material world: Food and moralities of consumption. Cultural Studies Review, v. 19, n. 1, p. 9-27, 2013.

DEBORD, G. Society of the Spectacle. New York: Zone Books, 2006.

DOS SANTOS, C. R. A. A comida como lugar de história: As dimensões do gosto. História: Questões \& Debates, v. 54, n. 1, p. 103-124, 2011.

EMERSON, R. M.; FRETZ, R. I.; SHAW, L. L. Writing Ethnographic Fieldnotes. Chicago: University of Chicago Press, 2011.

EMMEL, N.; CLARK, A. Learning to use visual methodologies in our research: A dialogue between two researchers. Forum Qualitative Sozialforschung, v. 12, n. 1, p. 1-11, 2011.

FAORO, R. Os Donos do Poder: Formação do patronato político brasileiro. Porto Alegre: Editora Globo, 2001.

FERNÁNDEZ-ARMESTO, F. Comida: uma história. Rio de Janeiro: Record, 2004.

FISCHLER, C. Food, self and identity. Social Science Information, v. 27, n. 2, p. 275-292, 1988.

FONSECA, S. A. Ingredientes da Aprendizagem Social: Um estudo na cozinha de um restaurante da grande São Paulo. 2013. Doctoral Dissertation (Doctor Degree in Business Administration) - Universidade Presbiteriana Mackenzie, São Paulo, 2013.

FOUCAULT, M. The Birth of Biopolitics: Lectures at the Collège de France, 1978-1979. New York: Picador, 2008

FREITAS, C. H. G.; MEDEIROS, C. R. O. The business of food \& eating: The postcolonial foodscape of Masterchef Brazil, social deconstruction \& individual resilience. In: LATIN AMERICAN AND EUROPEAN ORGANIZATION STUDIES CONFERENCE, 7., 2018, Buenos Aires. Proceedings... Bueno Aires: LAEMOS and IAE Business School, 2018.

GAMBATO, C.; GONÇALVES, R. B. Adaptação da cozinha francesa à cultura e ao paladar brasileiro. CULTUR, v. 11, v. 3, p. 58-86, 2017.

GEERTZ, C. The Interpretation of Cultures: Selected essays. New York: Basic Books, 1973.

GEERTZ, C. The world in pieces: Culture and politics at the end of the century. In: GEERTZ, C. Available Light: Anthropological reflections on philosophical topics. Princeton: Princeton University Press, 2000.

GIOUSMPASOGLOU, C.; MARINAKOU, E.; COOPER, J. Banter, bollockings \& beatings: The occupational socialisation process in Michelinstarred kitchen brigades in Great Britain and Ireland. International Journal of Contemporary Hospitality Management, v. 30, n. 3, p. 1882-1902, 2018.

GOBO, G. Doing Ethnography. London: Sage Publications, 2008.

GROSSBERG, L. Identity and cultural studies - Is that all there is? In: HALL, S.; DU GAY, P. Questions of Cultural Identity. London: Sage, 1996.

HALL, S. The Question of Cultural Identity. In: HALL, S.; HELD, D.; MCGREW, T. (Eds.). Modernity and its Futures. Cambridge: Polity, 1992.

HALL, S. When was 'the post-colonial'? Thinking at the limit. In: HAMBER, I.; CURTI, L. The Post-Colonial Question: Common skies, divided horizons. Abingdon: Routledge, 1996. 
HARVEY, D. The Condition of Postmodernity: An enquiry into the origins of cultural change. Oxford: Blackwell, 1989.

HATCH, M. J. Exploring the empty spaces of organizing: How improvisational jazz helps redescribe organizational structure. Organization Studies, v. 20, n. 1, p. 75-100, 1999.

HEGARTY, J. A.; O'MAHONY, G. B. Gastronomy: A phenomenon of cultural expressionism and an aesthetic for living. International Journal of Hospitality Management, v. 20, n. 1, p. 3-13, 2001.

HENDERSON, J. C. Celebrity chefs: Expanding empires. British Food Journal, v. 113, n. 5, p. 613-624, 2011.

HOBSBAWM, E. Introduction: Inventing traditions. In: HOBSBAWM, E.; RANGER, T. (Eds.). The Invention of Tradition. Cambridge: CUP, 2000.

HOFSTEDE, G. The business of international business is culture. International Business Review, v .3, n. 1, p. I-14, 1994.

IPIRANGA, A. S. R.; LOPES, L. L. S.; SOUZA, E. M. A experiência estética nas práticas culinárias de uma organização gastronômica. Organizações \& Sociedade, v. 23, n. 77, p. 191-210, 2016.

JAMESON, F. The antinomies of postmodernity. In: JAMESON, F. The Cultural Turn: Selected writings on the postmodern 1983-1998. London: Verso, 1998.

JOHNSON, B. Ethical issues in shadowing research. Qualitative Research in Organizations and Management, v. 9, n. 1, p. 21-40, 2014.

JOHNSTON, J.; BAUMANN, S. Foodies: Democracy and distinction in the gourmet foodscape. London: Routledge, 2010.

JOHNSTON, J.; GOODMAN, M. K. Spectacular foodscapes: food celebrities and the politics of lifestyle mediation in an age of inequality. Food, Culture and Society, v. 18, n. 2, p. 205-222, 2015.

JUDT, T. III Fares the Land. New York: Penguin, 2010.

LENGYEL, A.; GATLEY, A. Celebrity chefs and the construction of taste: From über macho to culinary crusader. In: COUNCIL FOR HOSPITALITY MANAGEMENT EDUCATION RESEARCH, LEARNING AND TEACHING ANNUAL CONFERENCE, 2016, Belfast. Proceedings... Belfast: Ulster University, 2016.

LÉVI-STRAUSS, C. Petit traité d'ethnologie culinaire. In: LÉVI-STRAUSS, C. L'Origine des Manières de Table. Paris: Plon, 1968.

LINARES, N. L.; TRINDADE, E. Processos de movimentos de significados simbólicos no consumo alimentar. Pensamento \& Realidade, v. 26, n. 2, p. 46-64, 2011.

MACIEL, M. E. Uma cozinha à brasileira. Revista Estudos Históricos, v. 1, n. 33, p. 26-39, 2004.

MAGUIRE, J. S. Introduction: Looking at food practices and taste across the class divide. Food, Culture \& Society, v. 19, n. 1, p. 11-18, 2016.

MCDONALD, S.; SIMPSON, B. Shadowing research in organizations: The methodological debates. Qualitative Research in Organizations and Management, v. 9, n. 1, p. 3-20, 2014.

MINTZ, S. W.; DU BOIS, C. M. The anthropology of food and eating. Annual Review of Anthropology, v. 31, n. 1, p. 99-119, 2002.

MONTEIRO, P. M. O homem cordial e a democracia quase impossível: Caráter típico-ideal e significado político da cordialidade em Raízes do Brasil. Ciência \& Trópicos, v. 24, n. 2, p. 333-357, 1996.
MUMBY, D. K.; STOHL, C. Power and discourse in organization studies: Absence and the dialectic of control. Discourse \& Society, v. 2, n. 3, p. 313-332, 1991.

QUIJANO, A. Coloniality of power and eurocentrism in Latin America. International Sociology, v. 15, n. 2, p. 215-232, 2000.

QUINLAN, E. Conspicuous invisibility: Shadowing as a data collection strategy. Qualitative Inquiry, v. 14, n. 8, p. 1480-1499, 2008.

RIBEIRO, D. O Povo Brasileiro: A formação e o sentido do Brasil. São Paulo: Companhia das Letras, 2006.

ROCHA, K. A. A evolução do curso de gastronomia no Brasil. Comportamento, Cultura e Sociedade, v. 4, n. 2, p. 11-27, 2016.

RODRÍGUEZ-FERRÁNDIZ, R. Culture industries in a postindustrial age: Entertainment, leisure, creativity, design. Critical Studies in Media Communication, v. 31, n. 4, p. 327-341, 2014.

ROZIN, P. Food and eating. In: KITAYAMA, S.; COHEN, D. (Eds.). Handbook of Cultural Psychology. New York: Guilford, 2007.

SAHLINS, M. Cosmologies of capitalism: The Trans-Pacific sector of "the world system". The British Academy: Proceedings, v.74, p. 1-51, 1988.

SAID, E. Orientalism. London: Penguin, 2003.

SAKURAI, C. Imigração japonesa para o Brasil: Um exemplo de imigração tutelada (1908-1941). In: FAUSTO, B. (Ed.). Fazer a América: A imigração em massa para a América Latina. São Paulo: EUDUSP, 1999.

SALATA, A. R. Quem é classe média no Brasil? Um estudo sobre identidades de classe. Dados - Revista de Ciências Sociais, v. 58, n. 1, p. 111-149, 2015.

SASSEN, S. The Global City: New York, London, Tokyo. Princeton: Princeton University Press, 1991.

SCHWARCZ, L. M.; STARLING, H. M. Brasil: uma biografia. São Paulo: Companhia das Letras, 2015.

SOUZA, J. A Elite do Atraso: Da escravidão a Bolsonaro. Rio de Janeiro: Sextante, 2019.

SOUZA FILHO, O. M. Discurso autoritário, discurso subserviente e discurso libertário na estrutura patrimonialista brasileira. In: I JORNADA INTERNACIONAL DE ESTUDOS DO DISCURSO. Anais... Maringá: Universidade Estadual de Maringá, 2008. Available at:

< http://www.ple.uem.br/jied/trab2.html >. Accessed on: Oct. 25, 2018.

SPIVAK, G. C. Can the subaltern speak? In: WILLIAMS, P.; CHRISTMAN, L. (Eds.). Colonial Discourse \& Post-Colonial Theory: A reader. New York: Columbia University, 1994.

SUAUDEAU, L. Cartas a um Jovem Chef. Rio de Janeiro: Elsevier, 2004.

TRIPADVISOR. Melhores Restaurantes: Uberlândia, MG, Brazil. 2018. Available at: <https://www.tripadvisor.com.br/Restaurants-g303400Uberlandia_State_of_Minas_Gerais.html>.Accessed on: Feb. 10, 2018.

VAN DIJK, T. A. Structures of discourse and structures of power. In: ANDERSON, J. A. Communication Yearbook 12. Abingdom: Routledge, 2012.

VÁSQUEZ, C.; BRUMMANS, B. H. J. M.; GROLEAU, C. Notes from the field on organizational shadowing as framing. Qualitative Research in Organizations \& Management, v. 7, n. 2, p. 144-165, 2012. 
WALKER, J. R. The Restaurant: From concept to operation. Hoboken: Wiley, 2014.

WARDE, A. The Practice of Eating. Cambridge: Polity, 2016.

WILSON, T. M.; DONNAN, H. Nation, state and identity at international borders. In: WILSON, T. M.; DONNAN, H. Border Identities: Nation and state at international frontiers. Cambridge: CUP, 1998.
ZAMAN, S., SELIM, N.; JOARDER, T. McDonaldization without a McDonald's. Food, Culture \& Society, v. 16, n. 4, p. 551-568, 2013.

ZUKIN, S.; LINDEMAN, S.; HURSON, L. The omnivore's neighborhood? Online restaurant reviews, race, and gentrification. Journal of Consumer Culture, v. 17, n. 3, p. 459-479, 2015.

Carlos Henrique Gonçalves Freitas

ORCID: https://orcid.org/0000-0002-9536-3693

Master of Business Administration from the Federal University of Uberlândia; Master in Applied Linguistics from Cardiff University; Master in Economics (interrupted) at Vrije Universiteit Amsterdam, School of Business \& Economics, The Netherlands. E-mail: chg.freitas@gmail.com

Cíntia Rodrigues

ORCID: https://orcid.org/0000-0001-7999-9002

PhD in Business Administration from Fundação Getulio Vargas (FGV EAESP); Adjunct Professor and Coordinator of the Doctorate and Master Programs at the Faculty of Management and Business of the Federal University of Uberlândia, Uberlândia - MG, Brazil. E-mail: cintia@ufu.br

Valdir Machado Valadão Junior

ORCID: https://orcid.org/0000-0001-7930-8056

Full Professor of Doctoral and Master Programs at the Faculty of Management and Business of the Federal University of Uberlândia, Uberlândia MG, Brazil. E-mail: valdirjr@ufu.br 